УДК 338.46:34(470-571)

Л. Н. Батьянова

Иркутский государственный университет, г. Иркутск, Российскал Федераиия

Ю. В. Борисова

Иркутский государственный университет, г. Иркутск, Российская Федерация

Е. В. Чигрина

Байкальский государственный университет, г. Иркутск, Российская Федерачия

С. В. Корнакова

Байкальский государственный университет, г. Иркутск, Российская Федерачия

\title{
ТЕРРИТОРИАЛЬНЫЕ ПРАВОВЫЕ И СОЦИАЛЬНО-ЭКОНОМИЧЕСКИЕ ПРОБЛЕМЫ УПРАВЛЕНИЯ ГОСУДАРСТВЕННОЙ СОБСТВЕННОСТЬЮ (НА МАТЕРИАЛАХ ИРКУТСКОЙ ОБЛАСТИ)
}

\begin{abstract}
АНнотАция. Проанализировав данные из Реестра государственной собственности Иркутской области об объектах государственной собственности, и рассмотрев особенности их управления, в статье выделен ряд основных проблем, возникающих в системе управления государственной собственностью Иркутской области: недостоверный и неполный характер сведений в Реестре. Низкий уровень экономической эффективности объектов государственной собственности; проблема эффективности и целевого использования государственной собственности областными предприятиями и учреждениями; неэффективное использование и использование не по назначению объектов государственной собственности, переданных в аренду. Определено, что для создания эффективной системы управления государственной собственностью необходимо усовершенствовать пути и механизмы управления государственным имуществом. Разработанные меры совершенствования системы управления государственной собственностью Иркутской области будут способствовать результативному управлению, повышению доходной части регионального бюджета, решению вопросов федерального и регионального значения, удовлетворению общественных потребностей.

кЛючЕВЫЕ словА. Управление государственной собственностью; имущество; объекты учета государственной собственности; безвозмездная передача.

ИНФОРМАЦИЯ О СТАТЬЕ. Дата поступления 14 июня 2017 г.; дата принятия к печати 11 октября 2017 г.; дата онлайн-размещения 25 октября 2017 г.
\end{abstract}

L. N. Batianova Irkutsk State University, Irkutsk, Russian Federation

Yu. V. Borisova Irkutsk State University, Irkutsk, Russian Federation

Ye. V. Chigrina

Baikal State University, Irkutsk, Russian Federation

S. V. Kornakova Baikal State University,

Irkutsk, Russian Federation

\section{TERRITORIAL LEGAL AND SOCIO-ECONOMIC PROBLEMS OF PUBLIC PROPERTY MANAGEMENT (A CASE STUDY OF IRKUTSK OBLAST)}

ABSTRACT. After analyzing the data from the State Property Registry of Irkutsk Oblast on objects of state ownership and considering the features of their management,

\section{Baikal Research Journal}


the article highlights a number of key issues arising from the management system of the public property of Irkutsk Oblast: the inaccurate and incomplete information in the Registry. A low level of economic efficiency of the public property objects; a problem of efficiency and target use of public property by the regional enterprises and institutions; an inefficient use and misuse of the public state property leased-out. It is determined that creating an effective system of state property management system needs improving the ways and mechanisms of the public property management. The measures of improving the system of public property management in Irkutsk Oblast will contribute to efficient management, to increase of the regional budget revenue, to solution of issues of federal and regional significance, to meeting the social needs. KEYWORDS. Public property management; property; accounting objects of public property; compensation-free transfer.

ARTICLE INFO. Received June 14, 2017; accepted October 11, 2017; available online October 25, 2017.

$\mathrm{C}$ целью реализации государственной политики Иркутской области в сфере имущественно-земельных отношений, в том числе управления и распоряжения государственной собственностью, создано Министерство имущественных отношений, основной функцией Министерства имущественных отношений в сфере управления государственной собственностью является организация работы по эффективному и целевому использованию областного имущества, а также сохранению объектов, имеющих социальное и стратегическое значение и предназначенных для выполнения полномочий Иркутской области как субъекта РФ.

С целью контроля проводятся проверки эффективности и целевого использования государственного имущества. Осуществляются как плановые, так и внеплановые проверки, в том числе контрольные мероприятия по поручению Губернатора Иркутской области, Правительства Иркутской области и правоохранительных органов Иркутской области с выездом на место. В 2016 г. было проведено 66 проверок, в том числе проверки по устранению ранее выявленных нарушений.

Уполномоченные органы изучают потребности государственных предприятий и учреждений в имуществе, находящемся в собственности Иркутской области. В этих целях областные предприятия и учреждения информируют об имуществе, которое находится в государственной собственности, а также запрашивают у них информацию о наличии потребности в закреплении областного имущества или о наличии потребности в имуществе, которое уже за ними закреплено [1, с. 46].

По результатам этих запросов государственная собственность Иркутской области может быть закреплена за областными предприятиями на праве хозяйственного ведения, оперативного управления или за областными учреждениями на праве оперативного управления, а также может быть изъято из хозяйственного ведения или оперативного управления в соответствии с законодательством [2, с. 145]. Содержание и поддержание имущества государственной собственности в удовлетворительном состоянии является обязанностью балансодержателей, у которых данное имущество находится в оперативном управлении.

По итогам работы Министерства в 2015 г. из общего числа нуждающихся в обеспечении жилыми помещениями детей-сирот от 18 лет в список Министерства на предоставление жилых помещений было включено 48 \% (3 504 человек), фактически обеспечить жилыми помещениями в 2015 году удалось 1000 человек. Использованная информация, необходимая для анализа, ис-

\section{Baikal Research Journal}

электронный научный журнал Байкальского государственного университета 
пользована из отчетов Министерства имущественных отношений Иркутской области о проделанной работе за 2015-2016 гг. ${ }^{1}$

К концу 2016 года на предоставление жилых помещений было включено 57 \% (4 446 человек). По итогам 2016 года число обеспеченных составило 745 человек из числа детей-сирот.

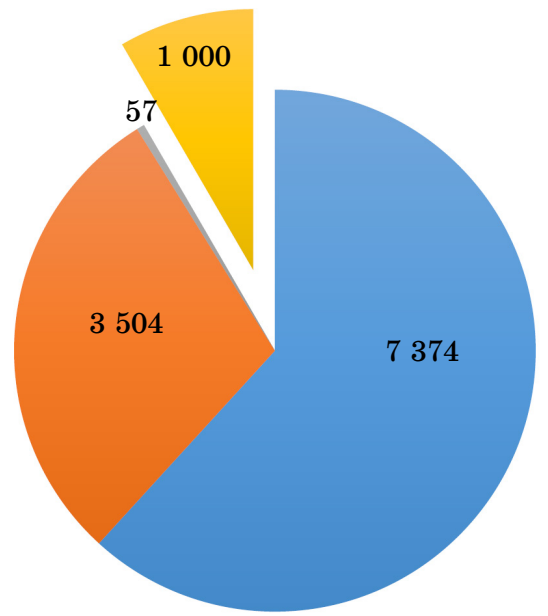

Всего нуждающихся детей-сирот от 18 лет

Из них включено в список на предоставление
Из них неисполненных судебных решений

Обеспечено жилыми помещениями детей-сирот

Рис. 1. Обеспечение жильли полещенияли детей-сирот в иифрах за 2015 год

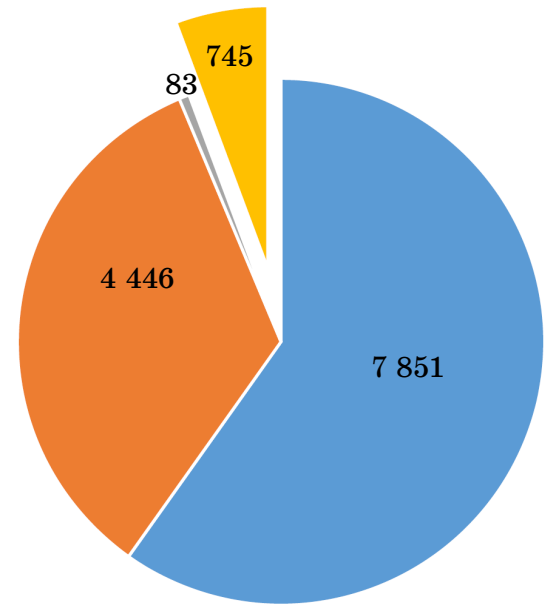

Всего нуждающихся детей-сирот от 18 лет

Из них включено в список на предоставление
Из них неисполненных судебных решений Обеспечено жилыми помещениями детей-сирот

Рис. 2. Обеспечение жилыми помещенияли детей-сирот в иифрах за 2016 год

${ }^{1}$ Отчеты Министерства имущественных отношений Иркутской области о проделанной работе за 2015-2016 гг. : утв. зам. председателя Правительства Иркутской обл. В. И. Кондрашовым. URL: http://irkobl.ru/ (дата обращения 07.06.2017).

\section{Baikal Research Journal}


ФЗ от 06.10.1999 г. № 184-ФЗ определено имущество, которое может находиться в собственности субъекта РФ. Для повышения уровня полноты информации о государственном имуществе и земельных участках ведется автоматизированная система учета государственного имущества и земель, которая включает в себя систематизированные данные обо всех объектах государственной собственности [3, с. 21]. Эти данные являются основой ведения Реестра государственной собственности Иркутской области.

На 01.01.2017 г. в Реестре государственной собственности Иркутской области числилось 30158 объектов учета, из них 12283 объектов недвижимости, 17875 объектов движимого имущества, 6 областных государственных унитарных предприятий, 591 областное государственное учреждение, 92 органа государственной власти Иркутской области и 17 хозяйственных обществ, акции (доли) которых находятся в областной государственной собственности. Важно отметить, что за период 2013-2016 гг. количество объектов движимого и недвижимого имущества увеличилось на $26 \%$. В табл. 1 показаны в динамике по годам данные об общем количестве недвижимого и движимого имущества, находящегося в государственной собственности Иркутской области. По данным видно, что общее количество объектов государственной собственности с 2014 г. возросло.

Таблица 1

Данные об общем количестве и стоимости имущества, находящегося в государственной собственности Иркутской области за 2014-2015 годы

\begin{tabular}{|l|r|c|c|c|r|r|}
\hline & \multicolumn{2}{|c|}{ на 01.01 .2015} & \multicolumn{2}{c|}{ на 01.01.2016 } & \multicolumn{2}{|c|}{ на 01.01.2017 } \\
\cline { 2 - 8 } & $\begin{array}{c}\text { Количе- } \\
\text { ство }\end{array}$ & $\begin{array}{c}\text { Стоимость } \\
\text { (тыс. p.) }\end{array}$ & $\begin{array}{c}\text { Количе- } \\
\text { ство }\end{array}$ & $\begin{array}{c}\text { Стоимость } \\
\text { (тыс. р.) }\end{array}$ & $\begin{array}{c}\text { Количе- } \\
\text { ство }\end{array}$ & $\begin{array}{c}\text { Стоимость } \\
\text { (тыс. р.) }\end{array}$ \\
\hline $\begin{array}{l}\text { Объекты } \\
\text { недвижимости }\end{array}$ & 9756 & 33379877,97 & 11168 & 38180593,31 & 12283 & 44782145,020 \\
\hline $\begin{array}{l}\text { Движимое } \\
\text { имущество }\end{array}$ & 14010 & 12204113,00 & 16456 & 23356528,26 & 17875 & 25877124,507 \\
\hline Итого & 23766 & 45583990,97 & 27624 & 61537121,57 & 58 & 70659269,527 \\
\hline
\end{tabular}

В табл. 2 показаны в динамике по годам данные о количестве объектов учета государственной собственности Иркутской области, внесенных в Реестр на соответствующую дату.

Таблица 2

Данные о количестве объектов учета государственной собственности Иркутской области, внесенных в Реестр на соответствующую дату

\begin{tabular}{|l|r|r|r|r|}
\hline \multicolumn{1}{|c|}{$\begin{array}{c}\text { Объекты учета областной } \\
\text { государственной собственности }\end{array}$} & $\begin{array}{c}\text { Общее } \\
\text { количество } \\
\text { на 01.01.14 }\end{array}$ & $\begin{array}{c}\text { Общее } \\
\text { количество } \\
\text { на 01.01.15 }\end{array}$ & $\begin{array}{c}\text { Общее } \\
\text { количество } \\
\text { на 01.01.16 }\end{array}$ & $\begin{array}{c}\text { Общее } \\
\text { количество } \\
\text { на 01.01.17 }\end{array}$ \\
\hline $\begin{array}{l}\text { Областные государственные унитарные } \\
\text { предприятия }\end{array}$ & 8 & 8 & 7 & 6 \\
\hline Областные государственные учреждения & 610 & 624 & 594 & 591 \\
\hline $\begin{array}{l}\text { Органы государственной власти Иркут- } \\
\text { ской области }\end{array}$ & 139 & 103 & 104 & 92 \\
\hline $\begin{array}{l}\text { Хозяйственные общества, акции (доли) } \\
\text { которых находятся в областной государ- } \\
\text { ственной собственности }\end{array}$ & 14 & 14 & 15 & 17 \\
\hline
\end{tabular}

Для наглядного представления числовых данных мы составили диаграмму, по которой видно, что среди объектов государственной собственности Иркутской об-

\section{Baikal Research Journal}


ласти большую долю занимают областные государственные учреждения, а меньше всего в собственности Иркутской области находится областных государственных унитарных предприятий.

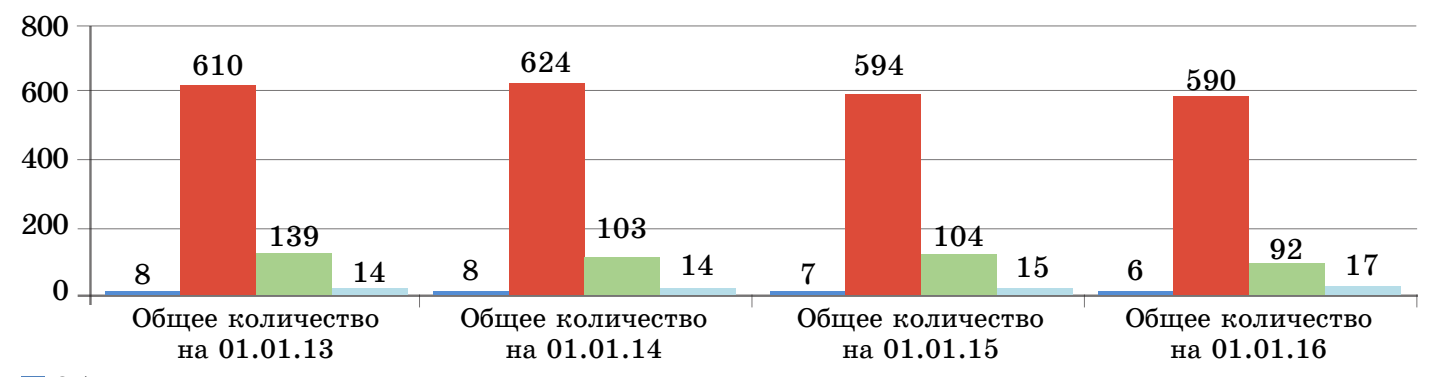

Областные государственные унитарные предприятия

Областные государственные учреждения

Органы государственной власти Иркутской области

Хозяйственные общества, акции (доли) которых в областной государственной собственности

Рис. З. Данные о количестве объектов учета государственной собственности

По состоянию на 31.12.2016 г. в Реестре значится 6 областных государственных унитарных предприятий. Из них текущую деятельность осуществляют 4 предприятия: ОГУЭП Энергосбытовая компания «Облкомммунэнерго-Сбыт», ОГУЭП «Электросетевая компания по эксплуатации электрических сетей «Облкоммунэнерго», ОГУП «Областной центр технической инвентаризации - Областное БТИ», ГУТПП «Фармация». Поскольку ОГУП «Печатный дом «Усть-Ордынский» находится в процедуре банкротства - конкурсное производство, а в отношении ОГУП «Окравтодор» на основании определения Арбитражного суда Иркутской области от 17.12. 2016 г. № А19-4550/2011 прекращено производство по делу о банкротстве. По состоянию на 31.12.2016 г. отчисления от прибыли ОГУП в бюджет Иркутской области составили 4097 тыс. р., что составляет $100 \%$ выполнения плана [3]. Положительный финансовый результат имеют два предприятия: ГУТПП «Фармация» и ОГУП «ОЦТИ-Областное БТИ» .

По состоянию на 1.01.2017 г. в Реестре числится 591 областное государственное учреждение, из них: 182 казенных, 127 автономных и 282 бюджетных учреждений.

C 2005 г. отмечается значительный рост количества областных государственных учреждений. В 2014 г. в Реестре было зарегистрировано самое большое количество ОГУ -624 .

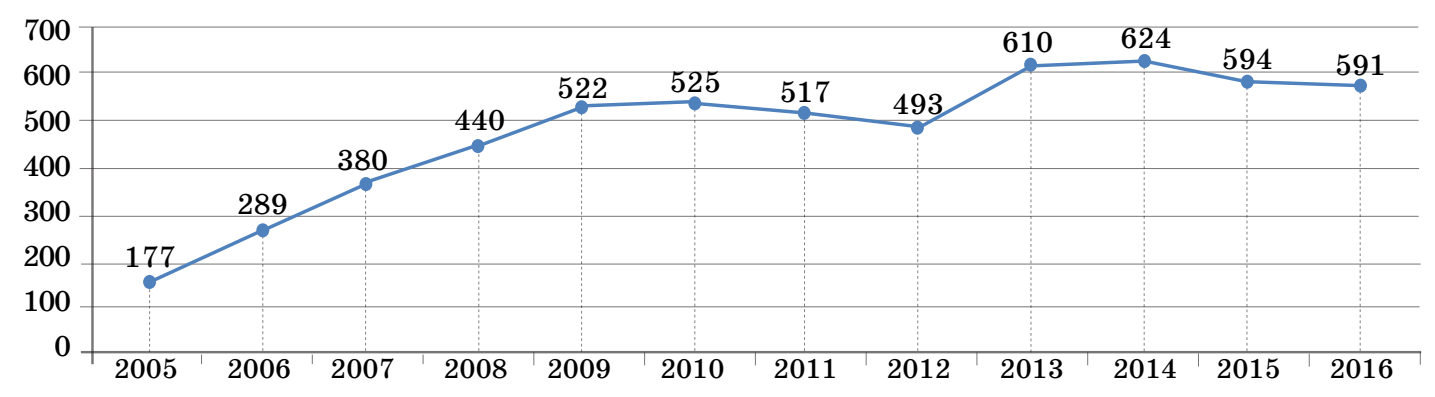

Рис. 4. Диналика увеличения количества ОГУ за 2005-2016 годы

\section{Baikal Research Journal}


Наибольшую часть в областных государственных структурах занимают областные государственные учреждения социальной сферы: ОГУ здравоохранения $26 \%$ от общего количества; ОГУ образования - $19 \%$ от общего количества; ОГУ социальной защиты $-21 \%$ от общего количества.

На 01.01.2017 г. в Реестр была внесена информация о зарегистрированных вещных правах Иркутской области на 2042 объекта недвижимости, в том числе на 1062 - о праве государственной собственности Иркутской области, 943 - о праве оперативного управления, на 37 - о праве хозяйственного ведения (табл. 3). По данным таблицы видно, что с 2012 г. количество объектов недвижимости, на которые зарегистрированы вещные права, увеличивается.

Таблица 3

Данные о количестве объектов учета государственной собственности Иркутской области, на которые зарегистрированы вещные права Иркутской области

\begin{tabular}{|c|c|c|c|c|c|c|}
\hline \multicolumn{7}{|c|}{ На период } \\
\hline \multirow{2}{*}{\multicolumn{2}{|c|}{$\begin{array}{l}\text { Количество объектов недвижи- } \\
\text { мости }\end{array}$}} & 01.01 .2013 & 01.01 .2014 & 01.01 .2015 & 01.01 .2016 & 01.01 .2017 \\
\hline & & 6971 & 8128 & 9756 & 11168 & 12283 \\
\hline \multirow{3}{*}{$\begin{array}{l}\text { Зарегистри- } \\
\text { ровано вещ- } \\
\text { ных прав }\end{array}$} & $\begin{array}{l}\text { Собственность Ир- } \\
\text { кутской области }\end{array}$ & $\begin{array}{r}1915 \\
(27,47 \%)\end{array}$ & $\begin{array}{r}2309 \\
(28,4 \%)\end{array}$ & $\begin{array}{r}3290 \\
(33,7 \%)\end{array}$ & $\begin{array}{r}4789 \\
(42,9 \%)\end{array}$ & $\begin{array}{r}5765 \\
(46,9 \%)\end{array}$ \\
\hline & $\begin{array}{l}\text { Оперативное управ- } \\
\text { ление }\end{array}$ & $\begin{array}{r}2863 \\
(33,90 \%)\end{array}$ & $\begin{array}{r}2910 \\
(35,80 \%)\end{array}$ & $\begin{array}{r}3259 \\
(33,4 \%)\end{array}$ & $\begin{array}{r}4232 \\
(37,9 \%)\end{array}$ & $\begin{array}{r}4800 \\
(39,08 \%)\end{array}$ \\
\hline & $\begin{array}{l}\text { Хозяйственное } \\
\text { ведение }\end{array}$ & $\begin{array}{r}303 \\
(4,34 \%)\end{array}$ & $\begin{array}{r}329 \\
(4,04 \%)\end{array}$ & $\begin{array}{r}376 \\
(3,85 \%)\end{array}$ & $\begin{array}{r}429 \\
(3,8 \%)\end{array}$ & $\begin{array}{r}462 \\
(3,76 \%)\end{array}$ \\
\hline
\end{tabular}

В 2016 г. Министерство проводило безвозмездную передачу имущества в связи с разграничением полномочий между органами государственной власти РФ и органами государственной власти Иркутской области, а также между органами государственной власти Иркутской области и органами местного самоуправления Иркутской области. В соответствии с установленным порядком, Территориальное управление Федерального агентства по управлению государственным имуществом в Иркутской области приняло решение о передаче имущества, находящегося в федеральной собственности, в государственную собственность Иркутской области.

Безвозмездная передача имущества из федеральной собственности Таблица 4 в государственную собственность Иркутской области за 2013-2015 годы

\begin{tabular}{|l|r|r|r|r|r|r|}
\hline \multirow{2}{*}{ Категория имущества } & \multicolumn{2}{|c|}{2014 г. } & \multicolumn{2}{|c|}{2015 г. } & \multicolumn{2}{c|}{2016 г. } \\
\cline { 2 - 8 } & $\begin{array}{c}\text { Коли- } \\
\text { чество }\end{array}$ & $\begin{array}{c}\text { Стоимость, } \\
\text { тыс. } \mathbf{p} .\end{array}$ & $\begin{array}{c}\text { Коли- } \\
\text { чество }\end{array}$ & $\begin{array}{c}\text { Стоимость, } \\
\text { тыс. p. }\end{array}$ & $\begin{array}{c}\text { Коли- } \\
\text { чество }\end{array}$ & $\begin{array}{c}\text { Стоимость, } \\
\text { тыс. p. }\end{array}$ \\
\hline Недвижимое имущество & 1 & - & 19 & 168709,46 & 63 & 345769,19 \\
\hline Движимое имущество & 1460 & 1497,16 & 1928 & 26958,92 & 4023 & 41605,56 \\
\hline
\end{tabular}

В табл. 5 указаны в динамике по годам данные о количестве недвижимого и движимого имущества, переданного из государственной собственности Иркутской области в федеральную собственность.

\section{Baikal Research Journal}

электронный научный журнал Байкальского государственного университета 
Таблица 5

Безвозмездная передача имущества из государственной собственности Иркутской области в федеральную собственность за 2014-2016 годы

\begin{tabular}{|l|r|r|r|r|r|r|}
\hline \multirow{2}{*}{ Категория имущества } & \multicolumn{2}{|c|}{2014 г. } & \multicolumn{2}{|c|}{2015 г. } & \multicolumn{2}{|c|}{2016 г. } \\
\cline { 2 - 7 } & $\begin{array}{c}\text { Коли- } \\
\text { чество }\end{array}$ & $\begin{array}{c}\text { Стоимость, } \\
\text { тыс. p. }\end{array}$ & $\begin{array}{c}\text { Коли- } \\
\text { чество }\end{array}$ & $\begin{array}{c}\text { Стоимость, } \\
\text { тыс. p. }\end{array}$ & $\begin{array}{c}\text { Коли- } \\
\text { чество }\end{array}$ & $\begin{array}{c}\text { Стоимость, } \\
\text { тыс. р. }\end{array}$ \\
\hline Недвижимое имущество & 59 & 220401,79 & 9 & 5907,42 & 10 & 33858,12 \\
\hline Движимое имущество & 84 & 19916,45 & 4033 & 24116,25 & 339 & 22087,9 \\
\hline Автотранспорт & 49 & 28085,90 & 31 & 14675,17 & 34 & 20023,5 \\
\hline
\end{tabular}

В табл. 6 указаны в динамике по годам данные о количестве недвижимого и движимого имущества, переданного из муниципальной собственности муниципальных образований Иркутской области в государственную собственность Иркутской области.

Для решения вопросов местного значения в 2016 г. из государственной собственности Иркутской области в муниципальную собственность муниципальных образований Иркутской области было передано 42 объекта недвижимого имущества, 49 земельных участков, 36 транспортных средств, 39227 единиц библиотечного фонда, 20 единиц спортивного инвентаря, 265088 единиц оборудования для школ и дошкольных образовательных учреждений.

Таблица 6

Безвозмездная передача имущества из муниципальной собственности муниципальных образований Иркутской области

в государственную собственность Иркутской области за 2014-2016 годы

\begin{tabular}{|l|r|r|r|r|r|r|}
\hline \multirow{2}{*}{ Категория имущества } & \multicolumn{2}{|c|}{2014 г. } & \multicolumn{2}{|c|}{2015 г. } & \multicolumn{2}{|c|}{2016 г. } \\
\cline { 2 - 8 } & $\begin{array}{c}\text { Коли- } \\
\text { чество }\end{array}$ & $\begin{array}{c}\text { Стоимость, } \\
\text { тыс. p. }\end{array}$ & $\begin{array}{c}\text { Коли- } \\
\text { чество }\end{array}$ & $\begin{array}{c}\text { Стоимость, } \\
\text { тыс. p. }\end{array}$ & $\begin{array}{c}\text { Коли- } \\
\text { чество }\end{array}$ & $\begin{array}{c}\text { Стоимость, } \\
\text { тыс. p. }\end{array}$ \\
\hline Недвижимое имущество & 92 & 367257,58 & 68 & 108754,18 & 143 & 8224,62 \\
\hline Движимое имущество & 37 & 4177,74 & 129 & 1842,33 & 192 & 9501,58 \\
\hline Транспортные средства & 2 & 475,0 & 2 & 1621,20 & - & - \\
\hline
\end{tabular}

Анализируя представленные данные в таблицах, можно сделать вывод, что в 2016 г. большее количество объектов недвижимого имущества было передано из муниципальной собственности муниципальных образований Иркутской области в государственную собственность Иркутской области, а большее количество объектов движимого имущества было передано из государственной собственности Иркутской области в муниципальную собственность муниципальных образований Иркутской области.

Таблица 7

Безвозмездная передача илущества из государственной собственности Иркутской области в муниципальную собственность муниципальных образований Иркутской области за 2013-2015 годы

\begin{tabular}{|l|r|r|r|r|r|r|}
\hline \multirow{2}{*}{ Категория имущества } & \multicolumn{2}{|c|}{2014 г. } & \multicolumn{2}{|c|}{2015 г. } & \multicolumn{2}{|c|}{2016 г. } \\
\cline { 2 - 8 } & $\begin{array}{c}\text { Коли- } \\
\text { чество }\end{array}$ & $\begin{array}{c}\text { Стоимость, } \\
\text { тыс. p. }\end{array}$ & $\begin{array}{l}\text { Коли- } \\
\text { чество }\end{array}$ & $\begin{array}{c}\text { Стоимость, } \\
\text { тыс. p. }\end{array}$ & $\begin{array}{c}\text { Количе- } \\
\text { ство }\end{array}$ & $\begin{array}{c}\text { Стоимость, } \\
\text { тыс. p. }\end{array}$ \\
\hline Недвижимое имущество & 177 & 1851585,76 & 190 & 1603856,62 & 113 & 1514350,82 \\
\hline Движимое имущество & 379355 & 607161,24 & 382783 & 632280,54 & 301816 & 254691,03 \\
\hline Транспортные средства & 184 & 207413,08 & 24 & 15604,87 & 36 & 7156,98 \\
\hline
\end{tabular}

Кроме безвозмездной передачи имущества, в 2016 г. в государственную собственность Иркутской области поступило имущество по договорам пожертвования

\section{Baikal Research Journal}


и договорам купли-продажи. В соответствии с договором купли-продажи было приобретено 4 жилых помещения в р. п. Куйтун и с. Андрюшино Куйтунского района для обеспечения медицинских работников жилыми помещения. В соответствии с договорами пожертвования в государственную собственность Иркутской области акционерное общество «Ангарский электролизный химический комбинат» передало имущество для обеспечения деятельности областного государственного автономного учреждения здравоохранения «Ангарская городская детская больница № 1», ООО «Ирказ-социальные объекты» передало имущество для обеспечения деятельности областного государственного автономного учреждения «Реабилитационный центр Шелеховский».

Помимо безвозмездной передачи имущества и договоров купли-продажи Иркутская область осуществляет передачу государственной собственности в аренду. По состоянию на 01.01.2017 г. действует 398 договоров аренды в отношении нежилых помещений, 12 договоров аренды движимого имущества и рекламного места, 68 договоров аренды на 643 земельных участка. Большую часть переданных в аренду площадей занимают субъекты малого и среднего предпринимательства: с ними заключено 201 договоров аренды (51 \% от общего количества договоров). С федеральными органами власти, учреждениями и предприятиями заключено 39 договоров аренды (10 \% от общего количества договоров). С некоммерческими организациями заключено 16 договоров аренды (4\% от общего количества договоров). С коммерческими организациями, которые не являются субъектами малого и среднего предпринимательства, заключено 101 договоров аренды $(25 \%$ от общего количества договоров). Органы местного самоуправления, муниципальные учреждения и предприятия арендуют имущество по 41 договору аренды, что составляет $4 \%$ и $10 \%$ соответственно.

На 31.12.2016 г. Иркутская область являлась акционером и участником 17 хозяйственных обществ, пакеты акций (доли) которых находятся в государственной собственности Иркутской области, и 6 областных государственных унитарных предприятий.

Имущество, неподлежащее использованию из-за его неудовлетворительного технического состояния, подлежит списанию. В табл. 8 представлена информация о списании имущества государственной собственности Иркутской области, по которой видно, что на 01.01.2017 г. было списано 38873 единицы государственной собственности, из них большее количество единиц объектов собственности было списано из библиотечного фонда, а также медицинская, компьютерная, офисная и другая техника, мебель и предметы быта.

Таким образом, можно сделать вывод, что в ведении Министерства имущественных отношений Иркутской области находится движимое и недвижимое имущество, земельные участки, а также специализированный жилищный фонд [4, c. 114]. Рассмотрев объекты государственной собственности Иркутской области и особенности их управления, мы проведем анализ проблем, возникающих в системе управления государственной собственностью Иркутской области.

Таблица 8

Информация о списании имущества государственной собственности Иркутской области по состоянию на 01.01.2017 год

\begin{tabular}{|c|l|r|r|}
\hline $\begin{array}{c}\text { № } \\
\text { п/п }\end{array}$ & \multicolumn{1}{|c|}{$\begin{array}{c}\text { Наименование областного государственного } \\
\text { имущества }\end{array}$} & $\begin{array}{c}\text { Количество } \\
\text { единиц }\end{array}$ & $\begin{array}{c}\text { Сумма по балансовой } \\
\text { стоимости, в млн р. }\end{array}$ \\
\hline 1 & $\begin{array}{l}\text { Автомобильный транспорт, самоходные маши- } \\
\text { ны и другие виды техники }\end{array}$ & 121 & 30,1 \\
\hline 2 & Объекты недвижимости & 43 & 23,11 \\
\hline
\end{tabular}

\section{Baikal Research Journal}

электронный научный журнал Байкальского государственного университета 
Окончание табл. 8

\begin{tabular}{|c|l|r|r|}
\hline $\begin{array}{c}\text { № } \\
\text { п/п }\end{array}$ & \multicolumn{1}{|c|}{$\begin{array}{c}\text { Наименование областного государственного } \\
\text { имущества }\end{array}$} & $\begin{array}{l}\text { Количество } \\
\text { единиц }\end{array}$ & \multicolumn{1}{c|}{$\begin{array}{c}\text { Сумма по балансовой } \\
\text { стоимости, в млн р. }\end{array}$} \\
\hline 3 & Дорогостоящая техника и оборудование & 12 & 34,28 \\
\hline 4 & $\begin{array}{l}\text { Медицинская, компьютерная, офисная и дру- } \\
\text { гая техника, мебель, предметы быта и др. }\end{array}$ & 638 & 145,79 \\
\hline 5 & Библиотечный фонд & 38059 & 1,39 \\
\hline \multicolumn{2}{|l|}{ Итого } & 38873 & 234,67 \\
\hline
\end{tabular}

Проведя анализ управления объектами государственной собственности в рамках региона, следует выделить ряд проблем. В целом проблемы управления государственной собственностью в субъектах заключаются в разделении объектов собственности и разграничении прав и полномочий органов власти. Одной из ключевых проблем управления государственной собственностью является недостаточная бюджетная, экономическая и социальная эффективность, которая выражается в низком уровне поступлений от собственности в бюджет и нецелевом использовании объектов собственности [5, с. 149].

Основной причиной недостаточной эффективности государственной собственности является низкое качество экономического законодательства, не обеспечивающее необходимых институциональных условий реализации потенциала собственности и полноценной правовой защиты. Существующие законодательные и нормативные акты в сфере регулирования государственной собственности субъектов РФ регулируют не все стороны ее функционирования.

Проанализировав данные из Реестра государственной собственности Иркутской области об объектах государственной собственности, и рассмотрев особенности их управления, мы выделили ряд основных проблем, возникающих в системе управления государственной собственностью Иркутской области.

К основным нарушениям и проблемам следует отнести:

1. Недостоверный и неполный характер сведений в Реестре. Причиной данной проблемы является несовершенство нормативно-правовых актов, регулирующих процессы учета имущества и отчетности областных учреждений и предприятий. Отсутствуют требования о сроках и периодичности предоставления информации об имуществе от правообладателей. Также на данный момент отсутствует массовая рыночная стоимость объектов в Реестре, которая бы отражала действительную ценность областного государственного имущества

2. Низкий уровень экономической эффективности объектов государственной собственности. Данная проблема объясняется тем, что большая часть объектов собственности в рыночной экономике имеет социальную направленность и лишь в меньшей степени направлена на выполнение фискальных функций.

3. Проблема эффективности и целевого использования государственной собственности областными предприятиями и учреждениями [6, с. 165]. В результате проверок эффективности и целевого использования государственного имущества Иркутской области в 2016 г. было выявлено, что на 149 объектов недвижимости и на 13 земельных участков не зарегистрировано право государственной собственности Иркутской области. Причиной этого является нарушения оформления прав на имущество в процессе передачи имущества из федеральной и муниципальной собственности в государственную собственность Иркутской области в связи с передачей полномочий. Также в 2016 г. по результатам проверки в 30 учреждениях выявлены факты неэффективного использования имущества.

4. Реализация положений Закона Иркутской области «О приватизации областного государственного имущества». В первую очередь это касается неисполнения

\section{Baikal Research Journal}

электронный научный журнал Байкальского государственного университета 
прогнозных планов приватизации. Прогноз поступлений от приватизации имущества государственной собственности в областной бюджет в 2016 г. был запланирован в сумме 108 100,00 тыс. . $^{2}$ Сложная рыночная ситуация и стремление органов власти продать публичное имущество по максимальной цене, привело к тому, что многие аукционы и торги посредством публичного предложения были признаны несостоявшимися по причине отсутствия заявок на участие в торгах. Таким образом, в бюджет поступают гораздо меньшие суммы, чем запланировано в прогнозном плане. По состоянию на 31.12.2016 г. доход областного бюджета от продажи имущества государственной собственности Иркутской области составил 31 623,98 тыс. p.

5. Неэффективное использование и использование не по назначению объектов государственной собственности, переданных в аренду. По результатам проверок в 2016 г. в отношении 9 объектов недвижимости заключены договоры аренды с нарушением законодательства, а в 3 договорах аренды нежилых объектов недвижимости занижена арендная плата. Годовые выпадающие доходы по причине заниженной арендной платы составляют 3953,7 тыс. p. Также в настоящее время до сих пор не решен вопрос об обязательном страховании областного имущества уполномоченным органом от поджога, затопления, причинения ущерба третьими лицами и т.д. Важно отметить, что в Реестре числится более 1000 объектов в деревянном исполнении, многие из которых переданы в аренду.

6. Проблема обеспечения сохранности и контроля над использованием детьми-сиротами по назначению жилых помещений $[7$, с.10], а также проблема обеспечения жильем сирот остается острой не только в Иркутской области, но и по всей стране. Министерство имущественных отношений Иркутской области является уполномоченным органом государственной власти по предоставлению детям-сиротам жилых помещений специализированного жилищного фонда Иркутской области.

7. Проблема материально-технического состояния объектов государственной собственности. Недостаточное выделение финансовых средств из областного бюджета на содержание имущества государственной собственности приводит к ухудшению технического состояния объектов и к увеличению физического износа, в результате чего объекты разрушаются и не подлежат ремонту. В 2016 г. Министерством имущественных отношений было согласовано списание имущества государственной собственности Иркутской области, не подлежащего ремонту и дальнейшему использованию, на общую сумму 234,67 млн. p.

8. Использование объектов территориального строительства, находящихся в государственной собственности Иркутской области. На поддержание и охрану данных объектов, не приносящих дохода, тратится значительная доля бюджетных средств. На практике отмечается расхищение объектов незавершенного строительства, их разрушение и приведение в непригодное состояние. Из-за отсутствия средств на завершение строительства возникает необходимость продавать эти объекты по ценам, которые не оправдывают исходные затраты. На 07.06.2017 г. в Реестре зарегистрировано 126 объектов незавершенного строительства.

Таким образом, можно сделать вывод, что в Иркутской области существуют нормативно-правовые и социально-экономические проблемы, которые препятствуют эффективному управлению государственной собственностью. Нарушение законодательства в процессе управления государственной собственностью, неэффективное использование имущества, недостаточное выделение финансовых

${ }^{2}$ Отчет Министерства имущественных отношений Иркутской области о проделанной работе за 2016 год : утв. зам. председателя Правительства Иркутской обл. В.И. Кондрашовым. URL: http:// irkobl.ru/ (дата обращения 07.06.2017).

\section{Baikal Research Journal}

электронный научный журнал Байкальского государственного университета 
средств на содержание имущества и др. является преградой для выполнения социальных обязательств перед населением, а также для реализации целей и задач, направленных на социально-экономическое развитие области.

Для создания эффективной системы управления государственной собственностью необходимо усовершенствовать пути и механизмы управления государственным имуществом. Существующие проблемы в сфере управления государственной собственностью требуют принятия единого комплексного Федерального закона, в котором будут закреплены публично-правовые аспекты собственности, порядок ее разграничения, учета, использования и контроля, процедура приватизации объектов собственности, сдача их в аренду, деятельность государственных предприятий и учреждений, нормы ответственности, способы обеспечения сохранности и эффективного использования объектов собственности и пр. [8, с. 16].

Рассмотрим основные меры по совершенствованию системы управления государственной собственностью Иркутской области.

1. Страхование жилых помещений специализированного жилищного фонда Иркутской области. В связи с выявленными многократными нарушениями в сфере использования жилых помещений детьми-сиротами необходимо проводить их страхование. Данный вопрос часто рассматривался Правительством Иркутской области, но ограниченность финансовых ресурсов не позволяет осуществлять мероприятия по страхованию. В настоящее время в Министерстве имущественных отношений рассматривают вопрос о проведении мероприятий по страхованию деревянных жилых помещений для детей-сирот. Финансирование этих мероприятий планируется обеспечить за счет перераспределения средств областного бюджета в рамках доведенных до Министерства бюджетных ассигнований на 2016 г. [9, с. 45].

2. Осуществление обязательного страхования областного имущества, переданного в аренду, от поджога, затопления, причинения ущерба третьими лицами и т.д. Страхование обеспечит защиту объектов недвижимости государственной собственности и внебюджетную компенсацию ущерба, который может быть нанесен объектам недвижимости. Страховщика следует выбирать на конкурсной основе, контроль над процессом страхования должно осуществлять Министерство имущественных отношений.

3. Перевод федеральных структур, прежде занимавших объекты областной собственности на безвозмездной основе, на договоры аренды. Данная мера повысит доходы областного бюджета [10, с. 120].

4. Регулярная передача в муниципальную собственность объектов недвижимости, которые не относятся к полномочиям Иркутской области. Данная мера будет способствовать сокращению расходов областного бюджета.

5. Разработка политики управления унитарными предприятиями. Данная политика должна быть направлена на контроль, сохранение и әффективное использование объектов государственной собственности. Руководителей унитарных предприятий следует назначать на конкурсной основе, за их деятельностью необходимо повысить государственный контроль. При повышении экономической эффективности функционирования предприятия необходимо снижать бюджетные расходы на их содержание [11, с. 54].

6. Планирование арендных процессов. Данное планирование можно осуществлять в двух формах: краткосрочное планирование (до года) и среднесрочное планирование (на 2-3 года). Данный план должен включать в себя количество объектов, подлежащих сдачи в аренду, показатели арендной платы, прибыль от аренды, различные льготы и т.п. Разработка нормативной и методологической базы повлияет на стимулирование повышения поступлений в бюджет от арендуемого имущества.

\section{Baikal Research Journal}

электронный научный журнал Байкальского государственного университета 
7. Составление реестра начальной стоимости объектов, которые могут сдаваться в аренду. Данная мера необходима для того, чтобы определить величину арендной платы и обосновать сумму за арендуемое имущество. Также необходимо проводить регулярную инвентаризацию всех договоров аренды. Процесс сдачи объектов собственности в аренду нужно сделать прозрачным и доступным для граждан [12, с. 30].

8. Активное применение концессионных соглашений. Необходимо заключать концессионные соглашения с областными государственными учреждениями на объекты государственной собственности, которые данные учреждения планируют использовать в своей деятельности.

9. Отсутствие правовой грамотности материально-ответственных лиц, без которой невозможна стабилизация социально-правовой ситуации в государстве [13, c. 99], ненадлежащий контроль, факты коррупции являются основными проблемами в управлении государственной собственностью Иркутской области. Руководители учреждений не регистрируют земли, не предоставляют в Министерство имущественных отношений необходимые документы. У Министерства отсутствуют какие-либо методические рекомендации в области управления и использования государственного областного имущества. Также в отношении объектов государственной собственности.

10. Применение новых информационных технологий в процессе организации системы статистической отчетности, инвентаризации объектов собственности и формирования Реестра. Для этого необходимо провести обновление компьютерной техники, средств передачи информации, создание единых информационных систем, позволяющих получать, накапливать, хранить, обновлять, перерабатывать и передавать информацию об объектах собственности. Важно отметить, что также необходимо подобрать специалистов, имеющих профессиональные навыки в области применения информационных технологий.

Таким образом, можно сделать вывод, что для эффективного управления государственной собственностью Иркутской области необходимо усовершенствовать законодательство по управлению государственной собственностью, обеспечить контроль и установить конкретную ответственность за сохранность и использование объектов государственной собственности. Разработанные нами меры по совершенствованию системы управления государственной собственностью Иркутской области будут способствовать результативному управлению, повышению доходной части регионального бюджета, решению вопросов федерального и регионального значения, удовлетворению общественных потребностей.

\section{Список использованной литературы}

1. Государственное и муниципальное управление собственностью / под ред. П. В. Кухтина, А. Б. Моттаевой. - М. : Мир науки, 2014. - 143 с.

2. Борисова Ю. В. Проблемы и направления совершенствования инвестиционного климата Иркутской области / Ю. В. Борисова, Е. С. Беляева, Т. В. Гладкова // Культура и взрыв: социальные смыслы в трансформирующемся обществе : материалы VII всерос. науч. интернет-конф. - Иркутск : Изд-во ИГУ, 2016. - С. 140-145.

3. Ануприенко В. Ю. Управление государственной собственностью в системе региональной экономики / В. Ю. Ануприенко. - М. : Экономика, 2007. - 249 с.

4. Буреш О. В. Региональный аспект развития системы управления государственной собственностью / О. В. Буреш, Д. Е. Бикбергенева // Вестник Оренбургского государственного университета. - 2010. - № 13. - С. 5-11.

5. Васильева Н. В. Правовое регулирование публичных доходов / Н. В. Васильева. Иркутск : Изд-во БГУ, 2015. - 194 с.

\section{Baikal Research Journal}

электронный научный журнал Байкальского государственного университета 
6. Бандурина Н. В. Основные направления совершенствования механизма управления государственной собственностью в Российской Федерации / Н. В. Бандурина // Черные дыры в Российском законодательстве. - 2011. - № 6. - С. 162-165.

7. Двинский М. Б. Управление государственной и муниципальной собственностью : конспект лекций / М. Б. Двинский, Е. Н. Почекутова. - Красноярск : СФУ, 2008. - 390 с.

8. Короткова О. И. Реформирование управления государственной собственностью одно из важнейших направлений государственной политики при реализации административной реформы / О. И. Короткова // Адвокат. - 2010. - № 6. - С. 41-45.

9. Короткова О. И. Структура, классификация и правовой режим государственного имущества / О. И. Короткова // Адвокат. - 2010. - № 3. - С. 41-46.

10. Невзорова Е. Н. Проблемы и перспективы управления муниципальной собственностью (г. Иркутск) / Е. Н. Невзорова // Государственное регулирование и устойчивое развитие муниципальных образований : сб. науч. тр. - Иркутск : Изд-во БГУЭП, 2004. C. $119-123$.

11. Бандурин В. В. Проблемы реформирования системы управления государственной собственностью / В. В. Бандурин, В. В. Касаткин, С. В. Торопов. - М. : Полиграфресурсы, 2000. -336 c.

12. Дмитриева О. Г. Особенности управления государственной собственностью в Российской Федерации / О. Г. Дмитриева // Российский экономический журнал. - 2013. № 2 . - С. $30-46$.

13. Корнакова С. В. Формирование правовой культуры личности / С. В. Корнакова, Е. В. Чигрина // Гражданское общество и правовое государство. — 2011. — Т. 1. C. 99-102.

\section{References}

1. Kukhtina P. V., Mottaevoi A. B. (ed.). Gosudarstvennoe i munitsipal'noe upravlenie sobstvennost'yu [Governmental and municipal property management]. Moscow, Mir nauki Publ., 2014. 143 p.

2. Borisova Yu. V., Belyaeva E. S., Gladkova T. V. Problems and directions of mastering investment climate in Irkutsk Oblast. Kul'tura i vzryv: sotsial'nye smysly $v$ transformiruyushchemsya obshchestve : materialy VII vseros. nauch. internet-konf. [Culture and Explosion: Social Meanings in Transforming Society. Materials of VII All-Russian Scientific Internet Conference]. Irkutsk State University Publ., 2016, pp. 140-145. (In Russian).

3. Anuprienko V. Yu. Upravlenie gosudarstvennoi sobstvennost'yu v sisteme regional'noi ekonomiki [Governmental property management in system of regional economy]. Moscow, Ekonomika Publ., 2007. 249 p.

4. Buresh O. V., Bikbergeneva D. E. Regional aspect of developing governmental property management system. Vestnik Orenburgskogo gosudarstvennogo universiteta = Bulletin of Orenburg State University, 2010, no. 13, pp. 5-11. (In Russian).

5. Vasil'eva N. V. Pravovoe regulirovanie publichnykh dokhodov [Legal regulation of public incomes]. Irkutsk, Baikal State University Publ., 2015. 194 p.

6. Bandurina N. V. Main directions of mastering the mechanism of governmental property management in the Russian Federation. Chernye dyry $v$ Rossiiskom zakonodatel'stve $=$ Black Holes in Russian Legislation, 2011, no. 6, pp. 162-165. (In Russian).

7. Dvinskii M. B., Pochekutova E. N. Upravlenie gosudarstvennoi $i$ munitsipal'noi sobstvennost'yu [Management of governmental and municipal property]. Krasnoyarsk, Siberian Federal University Publ., 2008. 390 p.

8. Korotkova O. I. Reforming governmental property management - one of the most important directions of national policy in implementing administrative reform. Advokat = Lawyer, 2010, no. 6, pp. 41-45. (In Russian).

9. Korotkova O. I. Structure, classification and legal regime of governmental property. Advokat $=$ Lawyer, 2010, no. 3, pp. 41-46. (In Russian).

10. Nevzorova E. N. Problems and prospects of municipal property (Irkutsk) management. Gosudarstvennoe regulirovanie i ustoichivoe razvitie munitsipal'nykh obrazovanii [Governmental regulation and sustainable development of municipal entities]. Irkutsk, Baikal State University of Econoimics and Law Publ., 2004, pp. 119-123. (In Russian).

\section{Baikal Research Journal}


11. Bandurin V. V., Kasatkin V. V., Toropov S. V. Problemy reformirovaniya sistemy upravleniya gosudarstvennoi sobstvennost'yu [Problems of reforming the system of public property management]. Moscow, Poligrafresursy Publ., 2000. 336 p.

12. Dmitrieva O. G. Features of public property management in the Russian Federation. Rossiiskii ekonomicheskii zhurnal = Russian Economic Journal. 2013, no. 2, pp. 30-46. (In Russian).

13. Kornakova S. V., Chigrina E. V. Formation of legal personality culture. Grazhdanskoe obshchestvo i pravovoe gosudarstvo = Civil Society and Legal State, 2011, vol. 1, pp. 99-102. (In Russian).

\section{Информация об авторах}

Батьянова Людлила Николаевна - кандидат философских наук, доцент, кафедра государственного и муниципального управления Институт социальных наук Иркутский государственный университет, 664003, г. Иркутск, ул. К. Маркса, 1.

Борисова Юлия Владилировна - кандидат экономических наук, доцент, кафедра государственного и муниципального управления Институт социальных наук Иркутский государственный университет, 664003, г. Иркутск, ул. К. Маркса, 1, e-mail: julia661@mail.ru.

Чигрина Елена Владимировна - кандидат экономических наук, доцент кафедры теории государства и права и социально-правовых дисциплин Байкальский государственный университет, 664003, г. Иркутск, ул. Ленина, 11, e-mail: ChigrinaEV@bgu.ru.

Корнакова Светлана Викторовна - кандидат юридических наук, доцент кафедры уголовного права, криминологии и уголовного процесса Байкальский государственный университет, 664003, г. Иркутск, ул. Ленина, 11, e-mail: Svetlana-kornakova@yandex.ru.

\section{Authors}

Lyudmila N. Batyanova - PhD in Philosophy, Associate Professor, Chair of Public and Municipal Administration, Institute of Social Sciences, Irkutsk State University, 1 K. Marx St., 664003, Irkutsk.

Yulia V. Borisova - PhD in Economics, Associate Professor, Chair of Public and Municipal Administration, Institute of Social Sciences, Irkutsk State University, 1 K. Marx St., 664003, Irkutsk; e-mail: julia661@mail.ru.

Yelena V. Chigrina - PhD in Economics, Associate Professor of the Department of Theory of State and Law and Socio-Legal Disciplines, Baikal State University, 11 Lenin St., 664003, Irkutsk; e-mail: ChigrinaEV@bgu.ru.

Svetlana $V$. Kornakova - PhD in Law, Associate Professor, Chair of Criminal Law, Criminology and Criminal Procedure, Baikal State University, 11 Lenin St., 664003, Irkutsk; e-mail: Svetlana-kornakova@yandex.ru.

\section{Для цитирования}

Батьянова Л. Н. Территориальные правовые и социально-экономические проблемы управления государственной собственностью (на материалах Иркутской области) / Л. Н. Батьянова, Ю. В. Борисова, Е. В. Чигрина, С. В. Корнакова // Baikal Research Journal. - 2017. - T. 8, № 3. - DOI : 10.17150/2411-6262.2017.8(3).10.

\section{For citation}

Batyanova L. N., Borisova Yu. V., Chigrina E. V., Kornakova S. V. Territorial legal and socio-economic problems of public property management (a case study of Irkutsk Oblast). Baikal Research Journal, 2017, vol. 8, no. 3. DOI: 10.17150/2411-6262.2017.8(3).10. (In Russian).

\section{Baikal Research Journal}

